\title{
External parasites of raptors (Falconiformes and Strigiformes): identification in an $e x$ situ population from Mexico
}

\author{
Jaqueline B. de Oliveira ${ }^{1,2}$, Tiziano Santos ${ }^{1,3}$, Christopher Vaughan ${ }^{1,4,5}$ \& Heber Santiago ${ }^{6}$
}

1. Instituto Internacional de Manejo y Conservación de Vida Sivestre (ICOMVIS), Universidad Nacional Autónoma, Apdo. 1350-3000, Heredia, Costa Rica.

2. Cátedra de Parasitologia, Departamento de Biologia, Universidade Federal Rural de Pernambuco (UFRPE), Rua Dom Manoel de Medeiros SN, Recife, CEP 52171-900, Pernambuco, Brasil; bianque01@yahoo.com.br

3. Laboratorio de Parasitología Veterinaria, Facultad de Estudios Superiores Cuautitlán Campo IV, Universidad Nacional Autónoma de México, Km 2.5 carretera a Cuautitlán-Toloyucan, San Sebastián Xhala, Cuautitlan Izcalli, Estado de Mexico, México, CP. 54714; tizizoo@yahoo.com

4. Department of Forest and Wildlife Ecology, University of Wisconsin-Madison, Madison, WI 53706 USA; cvaughan@wisc.edu

5. Associated Colleges of the Midwest, Apartado 2562-2050, San Pedro, Costa Rica; cvaughan@ acm.or.cr

6. Centro de Investigación y Conservación de Vida Silvestre (CIVS), Circuito Emiliano Zapata Norte, esq. con Circuito Emiliano Zapata Sur, s/n, col. El Pino, Los Reyes La Paz, Estado de México, México, CP. 56507; hrslopez@ yahoo.com

Received 19-V-2010. C Corrected 15-XII-2010. Accepted 21-I-2011.

\begin{abstract}
Raptorial birds harbor a variety of ectoparasites and the mayority of them are host specific. The aim of this study was to identify the ectoparasites of captive birds of prey from Mexico, as well as to verify their impact in the health of infested birds. Raptorial birds were confiscated and kept in captivity at the Centro de Investigación y Conservación de Vida Silvestre (CIVS) in Los Reyes La Paz, Mexico State. Seventy-four birds of prey (66 Falconiformes and eigth Strigiformes) of 15 species were examined for the presence of ectoparasites. We examined both juvenile and adult birds from both sexes. The overall prevalence was $16.2 \% ; 66.7 \%$ of raptors were infested with a single type of external parasite. Lice were the most prevalent ectoparasites (91.7\%), followed by feather mites and fleas (8.3\%). Degeeriella fulva (72.7\%), Craspedorrhynchus sp. (45.4\%) and Strigiphilus aitkeni $(9.1 \%)$ (Ischnocera, Philopteridae) were recovered from wings, head and neck regions of red-tailed hawk (Buteo jamaicensis), Swainson's hawk (B. swainsoni), Harris's hawk (Parabuteo unicinctus) and Barn owl (Tyto alba). Low lice infestation level was observed. Nymphs and females of feather mites Kramerella sp. (Pterolichoidea, Kramerellidae) were recovered solely from Barn owl (T. alba); while one Caracara (Caracara cheriway) was infested by the sticktight flea Echidnophaga gallinacea (Siphonaptera, Pulicidae). No clinical signs were observed in any infested bird. Probably the periodic use of organophosphorates was responsible of the low prevalence and lice infestation levels. The diversity of external parasites illustrates the importance of detailed revision of incoming and long-term captive raptors as part of responsible captive management. Five new hosts and geographic records are presented. Rev. Biol. Trop. 59 (3): 1257-1264. Epub 2011 September 01.
\end{abstract}

Key words: birds of prey, lice, feather mites, fleas, conservation, captivity.

As a result of the increased interest in raptors, a substantial volume of medical information is currently available (Fix \& Barrows 1990, Wendell et al. 2002, Naldo \& Samour 2004). According to several studies, the most common causes of morbidity in these birds are infectious and parasitic diseases, traumatic injuries, toxicosis and metabolic or nutritional diseases (Fix \& Barrows 1990, Deem et al. 1998, Wendell et al. 2002, Naldo \& Samour 2004).

External and internal parasites are one of the major determinants of population dynamics and adaptive processes, imposing fitness costs to their hosts and promoting genetic variation 
(Ortego et al. 2007). The documented external parasites of raptors include lice, feather mites, ticks, fleas, hippoboscid flies and fly larvae (Sohn \& Noh 1994, Morishita et al. 2001, Lierz et al. 2002, González-Acuña et al. 2005). Although raptors infested with these ectoparasites may show no clinical signs, severe infestation mainly by lice and feather mites, that may cause raggedlooking feathers and self-inflicted trauma; furthermore, some ectoparasites are vectors of several pathogens of rapine birds (Miller et al. 1997, Deem 1999, Morishita et al. 2001, Freitas et al. 2002). Successful work in the field of conservation and management of raptors requires detailed knowledge about their pathogens (Morishita 1997, Deem 1999). For this reason, in ex situ conservation programs, diagnosis and control of ectoparasites should be routine to incoming and long-term captive raptors of a large, multispecies bird collection. Moreover, it is important to emphasize that the knowledge of morbidity and mortality causes in captive raptors can provide a new insight into the health and conservation status of wild populations (Wendell et al. 2002, Deem et al. 2008).

Several Mexican raptors are included in the Appendices I and II of Convention on International Trade in Endangered Species of Wild Fauna and Flora (CITES) (Peterson \& Chalif 1989). Some species of endemic diurnal (Falconiformes) and nocturnal (Strigiformes) raptors are kept in captivity in Mexico, but studies about parasite fauna of these birds are scarce (Santos-Morin 2010). Therefore, the objective of this study was to identify ectoparasites of captive birds of prey from Mexico, as well as to verify their repercussion in the health status of infested birds.

\section{MATERIAL AND METHODS}

Study population: Between January and December 2008, 74 raptors (66 Falconiformes and eight Strigiformes) of 15 species (Table 1), juveniles and adults from both sexes (39 males and 35 female), were evaluated for the presence of ectoparasites. The birds were confiscated by

TABLE 1

External parasites of raptors kept in captivity at the Centro de Investigación y Conservación de Vida Silvestre (CIVS) of Mexico, January to December 2008

\begin{tabular}{|c|c|c|c|c|}
\hline Orden & Species & Examined & Infested & External parasites \\
\hline \multirow[t]{10}{*}{ Falconiformes } & Falco sparverius (American kestrel) & 8 & - & \\
\hline & F. peregrinus (Peregrine falcon) & 3 & - & \\
\hline & Caracara cheriway (Caracara) & 6 & 1 & Echidnophaga gallinacea \\
\hline & Buteo swainsoni (Swainson's hawk) & 3 & 3 & Craspedorrhynchus sp. \\
\hline & B. nitidus (Grey hawk) & 5 & - & \\
\hline & B. jamaicensis (Red-tailed hawk) & 18 & 7 & $\begin{array}{l}\text { Degeeriella fulva, } \\
\text { Craspedorrhynchus sp. } \\
\text { Craspedorrhynchus sp. }\end{array}$ \\
\hline & Buteo albicaudatus (White-tailed hawk) & 1 & - & \\
\hline & Parabuteo unicinctus (Harris’s hawk) & 20 & 2 & Degeeriella fulva \\
\hline & Buteogallus antrhacinus (Common black hawk) & 1 & - & \\
\hline & Accipiter striatus (Sharp-shinned hawk) & 1 & - & \\
\hline \multirow[t]{5}{*}{ Strigiformes } & Bubo virginianus (Great horned owl) & 4 & - & \\
\hline & Strix virgata (Mottled owl) & 1 & - & \\
\hline & Athene cunicularia (Burrowing owl) & 1 & - & \\
\hline & Megascops asio (Eastern screech owl) & 1 & - & \\
\hline & Tyto alba (Barn owl) & 1 & 1 & Strigiphilus aitkeni, Kramerella $\mathrm{sp}$. \\
\hline
\end{tabular}


the Secretaria del Medio Ambiente y Recursos Naturales (SEMARNAT) because their breeders were not licensed to have wildlife avian species. Birds were kept at the Centro de Investigación y Conservación de Vida Silvestre (CIVS) in Los Reyes La Paz (20²2' N, 98 59' W), state of Mexico, México. Other causes for admission at the CIVS included: acute traumatic injuries, electrocution, infectious diseases, orphaned young, metabolic and/or nutritional disease. All the birds were originally found in several counties from Mexico, but information regarding their origins was unavailable.

According to Morishita et al. (2001), freeliving raptors are defined as birds in captivity for fewer than 24 hours and admitted solely because of acute traumatic injuries, thus increasing the probability of otherwise healthy subjects, free from seasonal dietary stresses, and with normal parasite burdens. This way, the birds of the CIVS were long-term captive raptors.

The 74 raptors lived in 12 enclosures, definided as following: A $(n=8), B(n=11), C$ $(n=4), D(n=8), E(n=3), F(n=6), G(n=7), H$ $(n=1), I(n=10), J(n=6), K(n=3)$ and $L(n=7)$. Enclosures allowed limited flight and included sites protected from the weather and contained resting perches. Cages were encompassed by wire or plastic screen net siding, and birds were exposed to ambient weather conditions. Enclosures were raked two or three times/week.

Birds were fed three days/week with thawed chicks, mice or rats and given free access to water.

In order to evaluate the health status, according to weight the birds were classified as following: thin, good condition and obese (Greenacre 2003, Haire 2003).

For the parasite control in the routine of CIVS, the birds were dewormed (with fenbendazole or ivermectin) upon arrival and twice at year. Additionally, deworming was performed in the presence of clinical signs. Periodically, the infested birds were treated with organophosphorates dusting. Besides, birds were provided with veterinary medical attention and/or flight rehabilitation as required.
Ectoparasites collection: In order to obtain live material for different studies, the use of cotton bag; diethyl ether or insecticide were avoided. The birds were handled on a clean white surface and the whole plumage was profusely and systematically surveyed (using a magnifying glass) to remove, as far as possible, all ectoparasites specimens found (Pérez et al. 1996). On average, we thoroughly examined each bird about 20 minutes. Ectoparasites were collected manually or with tweezers and stored into a labeled vial with $70 \%$ alcohol. Lice and fleas were cleared in $10 \% \mathrm{KOH}$ (potassium hydroxide) while mites were cleared in lactophenol (Freitas et al. 2002). Ectoparasites were mounted on slides using Hoyer's medium (Pérez et al. 1996, Freitas et al. 2002). The arthropods were examined with a high-power microscope and identified with a standard identification keys and several published resources.

Prevalence and lice infestation level: The prevalence of external parasites was obtained according to Margolis et al. (1982). On the other hand, lice infestation level was defined as following: low (less than or equal to five lice observed after 10 random partings of the feahers), moderate (greater than five lice after 10 random partings of the feahers) and severe (moderate lice level and the presence of nits) (Morishita et al. 2001).

\section{RESULTS}

In general, $52.7 \%$ of the raptors presented good corporal condition. Thin and obese birds $(31.1 \%$ and $16.2 \%$, respectively) were also observed.

The overall prevalence of external parasites was $16.2 \%$ (74/12). Of the 66 Falconiformes examined, $11(16.7 \%)$ were infested; whereas with Strigiformes, infestation was present in only one $(12.5 \%)$ of eight examined. Eight birds $(66.7 \%)$ were infested with a single type of ectoparasite (Table 1). The birds infested were: Buteo jamaicensis (7/12), Parabuteo unicinctus (2/12), Buteo swainsoni 
(1/12), Caracara cheriway (1/12) and Tyto alba (1/12) (Table 1).

Chewing lice: Lice were the most prevalent ectoparasites, detected in $91.7 \%$ (11/12) of birds evaluated. The raptor species infested by lice were: $B$. jamaicensis (7/11), P. unicinctus (2/11), B. swainsoni (1/11) and T. alba (1/11) (Table 1). Lice (Ischnocera, Philopteridae) identified were: Degeeriella fulva $(72.7 \%)$ (8/11), Craspedorrhynchus sp. (45.4\%) (5/11) and Strigiphilus aitkeni $(9.1 \%)(1 / 11)$.

$B$. jamaicensis was the host of $D$. fulva and Craspedorrhynchus sp. Of the seven $B$. jamaicensis infested: $42.8 \%$ (3/7) presented coinfestation, $42.8 \%(3 / 7)$ presented single infestation by $D$. fulva and $14.3 \%$ (1/7) had single infestation by Craspedorrhynchus sp. (Table 1). D. fulva was located in the wings while Craspedorrhynchus sp. was recovered in the head, neck and wing regions.

Only one specimen of B. swainsoni had infestation by Craspedorrhynchus sp. (Table 1) on the head, neck and wings. D. fulva was also found in the wings from two (18.2\%) $P$. unicinctus (Table 1). The louse S. aitkeni was recovered in one specimen of $T$. alba (Table 1) and was found only in the wings. Overall, infestation level was low and no clinical signs were observed in any infested bird.

Feather mites: Nymphs and females of Kramerella sp. (Pterolichoidea, Kramerellidae) were recovered solely from T. alba, which also had lice infestation. No feather loss or damage was observed in infested bird.

Fleas: The flea embedded on the face of one $C$. cheriway was identified as sticktight flea Echidnophaga gallinacea (Siphonaptera, Pulicidae). The specimen recovered was a female.

No clinical signs were observed in the infested bird.

\section{DISCUSSION}

Raptors harbor a variety of ectoparasites, as demonstrated in this study, and the mayority of them are host specific. The overall prevalence of the external parasites was low (16.2\%), even with constant arrival of new infested birds to CIVS. Low prevalence probably occurred because of periodic treatment of infested birds with organophosphorates. In captivity, the prevalence of ectoparasites is low, contrary of what occurs in wild birds of prey (Lierz et al. 2002). Red-tailed hawk (B. jamaicensis), Harris's hawk (P. unicinctus), Swainson's hawk (B. swainsoni), Caracara (C. cheriway) and Barn owl (Tyto alba) were infested species.

Chewing lice: Lice are the most prevalent ectoparasites of raptors (Pérez et al. 1996, Deem 1999, Morishita et al. 2001, Cooper 2002) and in this study their prevalence was high $(91.7 \%)$. This high prevalence differs from the one reported by Morishita et al. (2001) and Pérez et al. (1996) in captive raptors from rehabilitation centres of United States $(34.3 \%)$ and Spain (42\%), respectively. In the present work, long-term captive infested raptors were in the most inhabited enclosures (B and I), which facilites the transmition (Cooper 2002, Whiteman \& Parker 2004). According to Whiteman \& Parker (2004), there is a positive relationship between ectoparasite infestation intensity and host density. Probably due to periodic treatment, the lice infestation level was low and no clinical signs were observed in any infested bird, which was also observed by Morishita et al. (2001). Despite this, captive birds of prey normally harbor small numbers of chewing lice that may increase in number when hosts are unable to preen themselves (Deem 1999, Morishita et al. 2001). Lice do not only affect the fitness, viability and productivity of their hosts, but also play a role as reservoirs and in the transmission of infectious diseases among them (Pérez et al. 1996). In sick raptors, severe lice infestations may occur and cause raggedlooking feathers, the bird may become highly irritated and cause self-inflicted trauma (Pérez et al. 1996, Miller et al. 1997, Deem 1999, Cooper 2002). In captivity, stress conditions are frequent; therefore infested raptors 
must be treated (Morishita 1997, Deem 1999, Morishita et al. 2001).

Degeeriella fulva and Craspedorrhynchus sp. were the most frequent lice, and they have been found in the Red-tailed hawk ( $B$. jamaicencis), Harris's hawk (P. unicinctus) and Swainson's hawk (B. swainsoni). According to Morishita et al. (2001), the trunk of the birds seems to be the predilection site of the lice, followed by the head region. In this study, D. fulva appeared to demonstrate a slight preference for wings (between the barbs of the long wing remiges), over head and neck regions (Pfaffenberger \& Rosero 1984, Pérez et al. 1996), while, Craspedorrhynchus sp. was found in the head, neck and body (thorax and wings), which was also observed in captive raptors from Spain (Pérez et al. 1996). These areas should be checked with attention for presence of ectoparasites during the physical exam.

It is important to emphasize that three specimen of seven infested B. jamaicencis (Red-tailed hawk) presented coinfestation, similar to reported by Pfaffenberger \& Rosero (1984). Furthermore, in other surveys, $B$. jamaicensis was the raptor that presented highest infestation levels (Pfaffenberger \& Rosero 1984, Morishita et al. 2001), so this falconiform species should receive special attention during the external examination in captive bird collections.

Degeeriella is one of the most frequent genera of louse from wild and captive falconiforms worldwide (Pérez et al. 1996, GonzálezAcuña et al. 2008), being D. fulva, D. regalis and Craspedorrhynchus americanus the species recorded in wild and captive $B$. jamaicensis (Morishita et al. 2001, Dalgleish 2009). Coinfestation by $D$. fulva and $C$. americanus was observed in $B$. jamaicensis from the United States by Pfaffenberger \& Rosero (1984), which considered that $C$.americanus is specific to this falconiform. Thereby, this is a new geographical record of D. fulva in B. jamaicensis.

Craspedorrhynchus sp. was also found in B. swainsoni (Swainsoni's hawk). Craspedorrhynchus species are relatively homogeneous morphologically and the male genitalia are the most reliable means for identifying the eleven Craspedorhynchus species from falconiformes (Pérez et al. 1996, Price et al. 1997, Morishita et al. 2001). Unfortunately, specimens of Craspedorrhynchus could not be identified at the species level because of poor conditions of the male genitalia, which occurred also in other surveys (Morishita et al. 2001, Dik 2006). Colpocephalum turbinatum, Degeeriella regalis, Kurodaia fulfofasciata and Laemobothrion maximum are registered in B. swainsoni worldwide (Dalgleish 2009), while Craspedorrhynchus platystomus have been recorded in captive falconiforms $B$. buteo and B. rufinus from Spain and Turkey (Pérez et al. 1996, Dik \& Aydenizöz-Özkayhan 2007). Similar to this study, specimens of Craspedorrhynchus from $B$. swainsoni could not be identified at the species level by Morishita et al. (2001). However, according these authors, the female louse recovered may have been $C$. hirsutus, reported solely in Ferruginous hawk (B. regalis).

Degeeriella emersoni and Laemobothrion maximum are the only lice species reported in Harris's hawk (P. unicinctus) (Dalgleish 2009). In this study, single infestation by $D$. fulva was observed in two specimens of Harris's hawks, which were in the same enclosure with the Red-tailed hawks infested by this louse. We believe that finding $D$. fulva in $P$. unicinctus may represent a direct accidental transfer from infested B. jamaicensis or the louse also could have been indirectly transferred by care-givers. Although most lice are host specific, several cases of secondary transfer among ecologically related hosts and captive species are recorded (Clayton 1990, Morishita et al. 2001). Therefore, $P$. unicinctus is presented as a new host of D. fulva.

Colpocephalum, Kurodaia and Strigiphilus are the genera of chewing lice from Strigiformes (Price \& Beer 1963, Morishita et al. 2001, Dalgleish 2009). However, Strigiphilus is the only genus of lice with its members restricted to owl hosts (Price \& Beer 1963, Clay 1966, Clayton 1990). K. subpachygaster, $C$. pectinatum and $C$. turbinatum were recorded 
in captive and free-ranging T. alba from Spain (Martín-Mateo 2006); while S. aitkeni was recovered only in free-ranging T. alba from United States (Morishita et al. 2001). In the present study, $S$. aitkeni was the only species recovered from the wings of the Barn owl ( $T$. alba). This louse occurs only on Barn owls, and only on those in the New World, Australia and Southeast Asia (Clay 1966, Pfaffenberger \& Rosero 1984, Clayton 1990, Morishita et al. 2001, Dalgleish 2009). Thereby, S. aitkeni is recorded for the first time in T. alba in Latin America.

Feather mites: Furthermore of louse $S$. aitkeni, feather mites Kramerella sp. were also recovered from the only specimen of Barn owl. Kramerella sp. is specific to Falconiformes and Strigiformes (Krantz 1978, Sohn \& Noh 1994, Gaud \& Atyeo 1996). However, there are no records in captive or free-ranging T. alba from Latin America. Despite coinfestation, no feather loss or damage was observed. Generally the presence of mites does not determine negative effects in the health of raptors, except in the mange cases by Knemidocoptes (Deem 1999, Miller et al. 2004).

Fleas: One noteworthy and surpring result of this study was the sticktight flea Echidnophaga gallinacea in one Caracara (C. cheriway). It is difficult to know how the bird had been infested because the bird was a long-term captive Caracara that lived with other long-term captive birds of the same species. One hypothesis is that the flea could have been accidentally transferred by care-givers through their clothes. E. gallinacea is a major pest of the domestic chicken (Gallus gallus) and despite the sticktight fleas' worldwide distribution and its broad host range, there is a scarcity of reports on flea infestations in captive and free-living avian species (Mactier 1970, Cooper \& Mellau 1992, Beaucournu et al. 2005, Boughton et al. 2006, Gyimesi et al. 2007). In raptors, this flea had been reported only in Elanus leucurus (black-shouldered kite) in Kenya (Cooper 2002). Although this flea has the potential to induce morbidity and mortality, no localized dermatitis or anemia was noted in response to ectoparasitism. Heavy infestations can result in anemia, blindness, severe pathology or death of birds if untreated (Mactier 1970, Cooper \& Mellau 1992, Boughton et al. 2006, Gyimesi et al. 2007). The impact of E. gallinacea on the C. cheriway confirms previous findings that sticktight fleas can be benign in captive avian hosts (Gyimesi et al. 2007). The infestation was treated with manual removal of flea combined with topical organophosphorates dusting and environmental treatment; and subsequent recheck exams did not reveal any fleas on this bird or any of the other birds housed in the same enclosure. It is important to mention that, despite being embedded around the face of bird, detection of the flea was not immediate. This case illustrates the importance of systematic and detailed revision procedures for incoming and long-term captive raptors as part of responsible captive management of a large, multispecies bird collection (Morishita 1997, Morishita et al. 2001, Gyimesi et al. 2007).

External parasites are frequent and can be deleterious for the health of birds of prey; thereby, the knowledge of the these parasites contributes and help ensure prompt, appropriate and judicious control (Morishita 1997, Deem 1999, Morishita et al. 2001, Joseph 2006, Willette et al. 2009). The monitoring of ectoparasitism should be a routine part of the health care of incoming and long-term captive raptors of conservation centers like the CIVS, since parasite prevention and monitoring programs require minimal time and cost (Morishita 1997).

Due to that the CIVS is also a rehabilitation center of wild birds of prey, the knowledge of the causes of morbidity and mortality of incoming and long-term captive raptors can provide insight about the health status and conservation of wild populations.

\section{ACKNOWLEDGMENTS}

We acknowledge the staff of the Centro de Investigación y Conservación de Vida Silvestre 
(CIVS), México. Tiziano Santos was supported in part by grants from the U.S. Fish and Wildlife Service.

\section{RESUMEN}

Las aves rapaces albergan una gran variedad de ectoparásitos y la mayoría de ellos son específicos de acogida. El objetivo de este estudio fue identificar los ectoparásitos de aves de presa en cautiverio en México y verificar su impacto en la salud de las aves. Se estudiaron 74 rapaces (66 Falconiformes y ocho Strigiformes) de 15 especies, juveniles y adultos de ambos sexos que fueron confiscadas y mantenidas en el Centro de Investigación y Conservación de Vida Silvestre (CIVS) en Los Reyes La Paz (20 22' $\mathrm{N}, 98^{\circ} 59^{\prime}$ W), estado de México. La prevalencia fue de $16.2 \% ; 66.7 \%$ de las rapaces estaban infestadas por un único tipo de ectoparásito. Los piojos fueron los más prevalentes (91.7\%), seguidos por los ácaros y las pulgas (8.3\%). Los piojos Degeeriela fulva (72.7\%), Craspedorhynchus sp. (45.4\%) y Strigiphilus aitkeni (9.1\%) fueron extraídos de las alas, cabeza y cuello de aguililla cola-roja (Buteo jamaicensis), aguililla migratoria (B. swainsoni), aguililla de Harris (Parabuteo unicinctus) y lechuza de campanario (Tyto alba). El ácaro Kramerella sp. fue extaído de T. alba; mientras que un Caracara (Caracara cheriway) estaba infestado por la pulga Echidnophaga gallinacea. No se observaron signos clínicos en ninguna de las aves infestadas. Probablemente el uso periódico de organofosforatos fue el responsable de la baja prevalencia y de los niveles de ingesta de piojos. La diversidad de ectoparásitos identificados ilustra la importancia de una detallada revisión de las rapaces en cautiverio. Cinco nuevos hospederos y registros geográficos son presentados.

Palabras clave: aves de presa, piojos, ácaros, pulgas, conservación, cautiverio.

\section{REFERENCES}

Beaucournu, J.C., B. Degeilh \& C. Guiguen. 2005. Bird fleas (Insecta: Siphonaptera): taxonomic diversity, biogeographical distribution. Parasite 12: 111-121.

Boughton, R.K., J.W. Atwell \& S.J. Schoech. 2006. An introduced generalist parasite, the sticktight flea (Echidnophaga gallinacea), and its pathology in the threatened Florida scrub-jay (Aphelocoma coerulescens). J. Parasitol. 92: 941-8.

Clay, T. 1966. The species of Strigiphilus (Mallophaga: Philopteridae) parasitic on the barn owls, Tyto (Tytoniddae). Aust J Entomol. 5: 10-17.
Clayton, D.H. 1990. Host specificity of Strigiphilus owl lice (Ischnocera: Philopteridae), with the description of new species and host associations. J. Med. Entomol. 27: 257-265.

Cooper, J.E. 2002. Birds of Prey: health and disease. Blackwell, United Kingdom.

Cooper, J.E. \& L.S. Mellau. 1992. Sticktight fleas (Echidnophaga gallinacea) on birds. Vet. Rec. 130: 108.

Dalgleish, R.C. 2009. Birds and their associated chewing lice (Downloaded: January 10, 2009, www.phthiraptera.org/Bird\%20list.html).

Deem, S.L. 1999. Infectious and parasitic diseases of raptors. Compend. Contin. Educ. Pract. Vet. 21: 329-338.

Deem, S.L., S.P. Terrel \& D.J. Forrester. 1998. A retrospective study of morbidity and mortality of raptors in Florida: 1988-1994. J. Zoo. Wildl. Med. 29: 160-164.

Deem, S.L., E. Ladwing, C. Cray, W.B. Karesh \& G. Amato. 2008. Health assessment of the ex situ population of St Vicent parrots (Amazona guildingii) in St Vicent and the Grenadines. J. Avian. Med. Surg. 22: 114-122.

Dik, B. 2006. Mallophaga species on long-legged buzzards (Buteo rufinus): new records from Turkey. Türkiye. Parazitol. Derg. 30: 226-230.

Dik, B. \& M. Aydenizöz-Özkayhan. 2007. Mallophaga species on long-legged buzzards (Buteo rufinus) in Turkey. Türkiye. Parazitol. Derg. 31: 298-301.

Fix, A.S. \& S.Z. Barrows. 1990. Raptors rehabilitated in Iowa during 1986 and 1987: a retrospective study. J. Wildl. Dis. 26: 18-21.

Freitas, M., M.C.N. Botêlho, A.S. Leite, V.S. Magalhães, A. Evencio-Sobrinho, R.A. Oliveira, M.H.C. Oliveira \& J.B. Oliveira. 2002. Ectoparásitos de aves silvestres mantidas em cativeiro no estado de Pernambuco, Brasil. Entomol. vectores 9: 25-34.

Gaud, J. \& W.T. Atyeo. 1996. Feather Mites of the World (Acarina, Astigmata): the supraspecific taxa. Ann. Sci. Zool. Mus. R. Afr. Cent. 277: 1-193.

González-Acuña, D., J.M. Venza, J.E. Keirans, R.G. Robins, S. Ippi \& A.A. Guglielmone. 2005. New host and locality records for the Ixodes auritulus (Acari: Ixodidae) species group, with a review of host relationships and distribution in the Neotropical zoogeographic region. Exp. Appl. Acarol. 37: 147-156. 
González-Acuña, D., K. Ardiles, R.A. Figueroa, C. Barrientos, P. González, L. Moreno \& A. Cicchino. 2008. Lice of Chilean diurnal raptors. J. Raptor. Res. 42: $281-286$

Greenacre, C. 2003. The avian patient, p. 5-29. In B. Ballard \& R. Cheek (eds.). Exotic animal medicine for the Veterinary Technician. Blackwell, USA.

Gyimesi, Z.S., E.R. Hayden \& E.C. Greiner. 2007. Sticktight flea (Echidnophaga gallinacea) infestation in a Victoria crowned pigeon (Goura victoria). J. Zoo. Wildl. Med. 38: 594-6.

Haire, M. 2003. The role of the veterinary technician in wildlife rehabilitation, p. 237-306. In B. Ballard \& R. Cheek (eds.). Exotic animal medicine for the Veterinary Technician. Blackwell, USA.

Joseph, V. 2006. Raptor medicine: an approach to wild, falconry, and educational birds of prey. Vet. Clin. North Am. Exot. Anim. Pract. 9: 321-345.

Krantz, G.W. 1978. A manual of acarology. Oregon State University, USA.

Lierz, M., T. Göbel \& R. Schuster. 2002. Occurrence of parasites in indigenous birds of prey and owls. Berl. Munch. Tierarztl. Wochenschr. 115: 43-52.

Mactier, L.A. 1970. Stickfast flea, Echidnophaga gallinacea, on wild birds. Aust. Vet. J. 46: 31.Margolis, L., G.W. Esch, J.C. Holmes, A.M. Kuris \& G.A. Schad. 1982. The use of ecological terms in parasitology (report of an ad hoc committee of the American Society of Parasitologists). J. Parasitol. 68: 131-133.

Martín-Mateo, M.P. 2006. Diversidad y distribución de las especies de Mallophaga (Insecta) en aves y mamíferos de la comunidad de Madrid. Graellsia 62: 21-32.

Miller, M., P. Ewins \& T. Galloway. 1997. Records of ectoparasites collected on Ospreys from Ontario. J. Wild1. Dis. 33: 373-376.

Miller, D.S., G.F. Taton-Allen \& T.W. Campbell. 2004. Knemidokoptes in a Swainson's hawk, Buteo swainsoni. J. Zoo. Wildl. Med. 35: 400-402.

Morishita, T.Y. 1997. Parasites of raptors and developing a parasite monitoring and prevention program. Wildl. Rehabil. 15: 119-133.

Morishita, T.Y., J.W. Mertins, D.G. Baker, C.M. Monahan \& D.L. Brooks. 2001. Ocurrence and species of lice on free-living and captive raptors in California. J. Avian Med. Surg. 15: 288-292.
Naldo, J.L. \& J.H. Samour. 2004. Causes of morbidity and mortality in falcons in Saudi Arabia. J. Avian Med. Surg. 18: 229-241.

Ortego, J., J.M. Aparicio, G. Calabuig \& P.J. Cordero. 2007. Risk of ectoparasitism and genetic diversity in a wild lesser kestrel population. Mol. Ecol. 16: 3712-3720

Pérez, J.M., I. Ruíz-Martínez \& J.E. Cooper. 1996. Occurrence of chewing lice on spanish raptors. Ardeola 43: $129-138$.

Peterson, R.T. \& E.L. Chalif. 1989. Aves de México. Guía de campo. Diana, México.

Pfaffenberger, G.S. \& J.F. Rosero. 1984. Mallophaga from five raptor species in eastern New Mexico. J. Wildl. Dis. 20: 65-66.

Price, R.D. \& J.R. Beer. 1963. The Kurodaia (Mallophaga: Laemobothridae) parasitic on the Strigiformes, with a key to the species of the genus. Ann. Entomol. Soc. Am. 56: 849-857.

Price, R.D., R.L. Palma \& R.A. Hellenthal. 1997. New synonymies of chewing lice (Phthiraptera: Amblycera, Ischnocera) described from the Falconiformes (Aves). Eur. J. Entomol. 94: 537-545.

Santos-Morin, T. 2010. Diagnóstico y control de parásitos: repercusión en la conservación ex situ de aves rapaces en México. Tesis de Maestría, Universidad Nacional Autónoma, Heredia, Costa Rica.

Sohn, B.O. \& Y.T. Noh. 1994. Feather mites Kramerellidae and Pterolichidae in Korea (Acari, Pterolichoidea). Kor. J. Parasitol. 32: 75-83.

Wendell, M.D., J.M. Sleeman \& G. Kratz. 2002. Retrospective study of morbidity and mortality of raptors admitted to Colorado State University Veterinary Teaching Hospital during 1995 to 1998. J. Wildl. Dis. 38: 101-106.

Whiteman, N.K. \& P.G. Parker. 2004. Effects of host sociality on ectoparasite population biology. J. Parasitol. 90: 939-947.

Willette, M., J. Ponder, L. Cruz-Martinez, L. Arent, I. Bueno-Padilla, O.N. de Francisco \& P. Redig. 2009. Management of select bacterial and parasitic conditions of raptors. Vet. Clin. North Am. Exot. Anim. Pract. 12: 491-517. 